\title{
A sutureless technique using cyanoacrylate adhesives when creating a stoma for extremely low birth weight infants
}

\author{
Satoko Nose ${ }^{1}$, Takashi Sasaki ${ }^{1}$, Ryuta Saka' ${ }^{1}$ Kyoko Minagawa² and Hiroomi Okuyama ${ }^{2,3^{*}}$
}

\begin{abstract}
Purpose: Intestinal perforation and necrotizing enterocolitis (NEC) are neonatal intestinal emergencies that are especially common in premature infants. While prompt surgical intervention, including stoma creation, is often required, the optimal surgical treatment has been controversial because of the substantial risks related to the stoma creation and management. The use of a tissue adhesive may have some advantages over the use of sutures when creating an intestinal stoma in extremely low birth weight (ELBW) infants. The purpose of this report was to present a novel approach for creating a stoma using a tissue adhesive in ELBW infants.
\end{abstract}

Methods: A total of eight ELBW infants that underwent laparotomy with the creation of intestinal stomas using cyanoacrylate adhesive at our institution between 2009 and 2014 were enrolled. The clinical parameters, including the length of the operation, intra- and postoperative complications and the outcomes were evaluated.

Results: The median body weight and gestational age at birth were $630 \mathrm{~g}$ and 24.3 weeks, respectively. The median age at referral was 11.5 days. The median length of the procedure was $58.5 \mathrm{~min}$, including the inspection and resection of the intestine. All procedures were completed without any intraoperative complications. There were no postoperative complications associated with the stoma. Two patients died of the associated septic status.

Conclusions: Sutureless enterostomy using cyanoacrylate adhesive is a simple technique which has the potential to reduce the incidence of complications related to the intestinal stoma in ELBW infants.

Keywords: Extremely low birth weight infants (ELBW infants), Intestinal perforation, Intestinal stomas, Tissue adhesive glue

\section{Background}

Despite recent advances in neonatal care, idiopathic intestinal perforation and necrotizing enterocolitis (NEC) occur increasingly in extremely low birth weight (ELBW) infants with high mortality and morbidity rate. The Japanese Society of Pediatric Surgeons stated that the mortality rate of intestinal perforation ranged from $16.9 \%$ in 2003-2007, to $18.2 \%$ in 2008-2013, and of NEC was still over $20 \%$. These data show that the next step to improve overall survival among ELBW infants is to overcome intestinal perforation requiring surgical management.

\footnotetext{
*Correspondence: okuyama@pedsurg.med.osaka-u.ac.jp

${ }^{3}$ Department of Pediatric Surgery, Osaka University Graduate School

of Medicine, Suita 565-0871, Osaka, Japan

Full list of author information is available at the end of the article
}

However, the timing and method of surgical management remain controversial because of the high mortality rates of the conditions (Blakely et al. 2005).

Emergency laparotomy and diverting enterostomy for an intestinal perforation in ELBW infants are associated with a substantial risk of complications related to the stoma because of their extreme prematurity. The key factors associated with a successful abdominal surgery in ELBW infants include a less invasive procedure and better management of a stoma. Suturing for a stoma in the intestine requires a longer operation and meticulous technique to avoid penetration of the extremely thin bowel wall in ELBW. Cyanoacrylate tissue adhesive has been used to seal wounds in accident and emergency departments, and to cover surgical wounds in the eyes

\section{黛 Springer}

(C) 2016 Nose et al. This article is distributed under the terms of the Creative Commons Attribution 4.0 International License (http://creativecommons.org/licenses/by/4.0/), which permits unrestricted use, distribution, and reproduction in any medium, provided you give appropriate credit to the original author(s) and the source, provide a link to the Creative Commons license, and indicate if changes were made. 
and during plastic surgery, including in the pediatric population (Farion et al. 2002; Singer and Thode 2004). In the field of pediatrics, there is a randomized controlled study that cyanoacrylate tissue adhesives is as alternative to subcuticular suture for pediatric herniotomies (Ong et al. 2002). Recently cyanoacrylate adhesives are applied to circumcision for boys (Voznesensky et al. 2015), to congenital cardiac surgery as skin adhesive and bronchopleural fistula in neonates (Vida et al. 2015; Saleemi et al. 2013).

Furthermore, there have been experimental studies that have shown the advantages of suture-free intestinal application using tissue adhesive, because tissue adhesives do not impair the tissue perfusion (Weiss and Haj 2001; Kanellos et al. 2002; Faion et al. 2011). However, there have so far been no reports of cyanoacrylate tissue adhesive use for stoma creation.

We have been using cyanoacrylate adhesives as a substitute for sutures to simplify the intestinal stoma creation since 2009. This retrospective study aimed to determine whether cyanoacrylate adhesives are safe and effective in ELBW infants undergoing the creation of an intestinal stoma for a perforated intestine.

\section{Methods}

This study was approved by the local Research Ethics Board. We performed a chart review of all cases of ELBW infants that underwent laparotomy with the creation of intestinal stomas using cyanoacrylate adhesives at the Hospital of Hyogo College of Medicine between 2009 and 2014. The following demographic data and clinical outcomes were collected: sex, gestational age at birth, body weight at birth, the underlying illness, early use of antenatal steroids and indomethacin, the length of the operation and the intra- and postoperative complications.

The surgical procedure was performed in the neonatal intensive care unit because the status of these infants frequently was life-threatening.

\section{Surgial work-up}

All patients initially received antibiotic prophylaxis (aminobenzylpenicillin and cefotaxime). Analgosedation with fentanyl and midazolam were initially used for all mechanically ventilated ELBW infants undergoing intensive care at this institute. Vecuronium bromide was used during the procedure.

\section{Surgical technique}

The abdominal cavity was inspected through a laparotomy under local anesthesia. Thereafter, the site of intestinal perforation was identified and pulled out via the laparotomy wound. The abdominal wall was then closed in two layers. The muscle layers were closed, and the exteriorized intestine was fixed to the abdominal wall using cyanoacrylate adhesive at the end of the procedure (Fig. 1).

\section{Statistical analyses}

The median with range was used to describe continuous variables. The statistical analysis was performed using the GraphPad Prism software package (version 6; GraphPad Software, Inc., CA, USA).

\section{Results}

A total of 16 ELBW infants underwent laparotomy with the creation of intestinal stomas during the study period. Of those, eight infants were treated using cyanoacrylate adhesives. The patient characteristics are summarized in Table 1 . The median body weight and gestational age at birth were $630 \mathrm{~g}$ and 24.3 weeks, respectively. The underlying illness was focal intestinal perforation in four patients, meconium-related ileus in two, meconium peritonitis in one and a congenital Treves' field transmesenteric hernia in one infant. Three patients were small for gestational age.

The median length of the operative, including inspection and resection of the intestine, was 58.5 min (range 29-106 min). None of the patients had any intraoperative complications. Although one infant required re-operation for intestinal stoma creation due to an iatrogenic injury, none had postoperative complications related to the stoma, including peritonitis caused by the migration of the stomal intestine into the peritoneal cavity, stomal prolapse or a stitch sinus. The appearance of stomas was good in most cases (Fig. 2).

The mean duration of hospitalization was 234.5 days. Two infants died of progressive liver failure; one was related to sepsis due to uncontrollable peritonitis even after the operation, the other was associated with familial idiopathic thrombocytopenia.

The follow-up time ranged from 5 months to 5 years. During the follow-up period, there were no late death or abdominal complications related to the stoma creation using sutureless technique.

\section{Discussion}

As intestinal perforation in ELBW infants is likely to result in mortality or long-term serious consequences, and the surgical treatment of intestinal perforation in ELBW infants is still challenging (Eicher et al. 2012; Rees et al. 2007; Murthy et al. 2014). Although the standard approach for patients with an intestinal perforation is surgical resection of the involved bowel with the creation of intestinal stomas, several authors have suggested that primary peritoneal drainage under local anesthesia is better than laparotomy in ELBW infants. These 

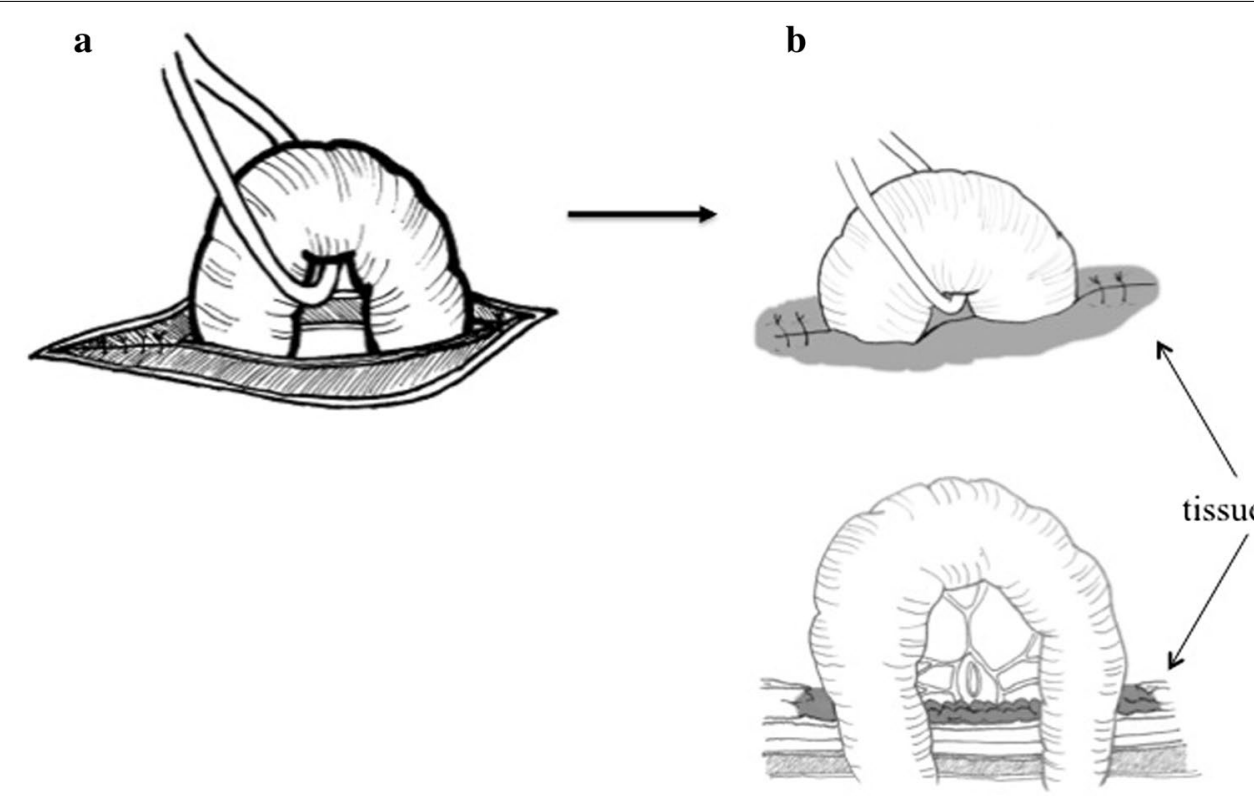

Fig. 1 A schematic illustration of stoma creation using the cyanoacrylate adhesive. The muscle layers were closed (a) and the intestine was fixed to the abdominal wall using cyanoacrylate adhesive at the skin level (b)

Table 1 Patient demographics and clinical characteristics

\begin{tabular}{ll}
\hline & Median $(\mathbf{n}=\mathbf{8})$ \\
\hline Sex (M/F) & $3 / 5$ \\
Caesarean section & 8 \\
Gestational age at birth (weeks) & $24.3(23.0-32.4)$ \\
Apgar score at 1 min & $3.5(2-7)$ \\
Apgar score at 5 min & $5.5(4-8)$ \\
Body weight at birth (g) & $630(412-926)$ \\
Early use of indomethacin & 0 \\
Early use of antenatal steroids & 5 \\
Age at operation (days) & $11.5(2-41)$ \\
Peritoneal drainage before stoma creation & 0 \\
\hline
\end{tabular}

Continuous data are expressed as the medians with the range studies used peritoneal drainage based on the belief that these infants could not tolerate laparotomy (Michel et al. 2004; Gollin et al. 2003). While peritoneal drainage may offer some initial advantages because it is relatively easy to perform and less invasive than surgery, a subsequent laparotomy is required for clinical deterioration and bowel trouble in $28-74 \%$ of cases (Moss et al. 2006; Rees et al. 2008; Hunter et al. 2008; Sola et al. 2010). The special problems related to a laparotomy in ELBW infants include an increased susceptibility to infection, water and heat loss from the exposed bowel, and postoperative ventilator difficulties due to abdominal distension (Lai et al. 2010). The key factor associated with a successful abdominal surgery in ELBW infants includes the use
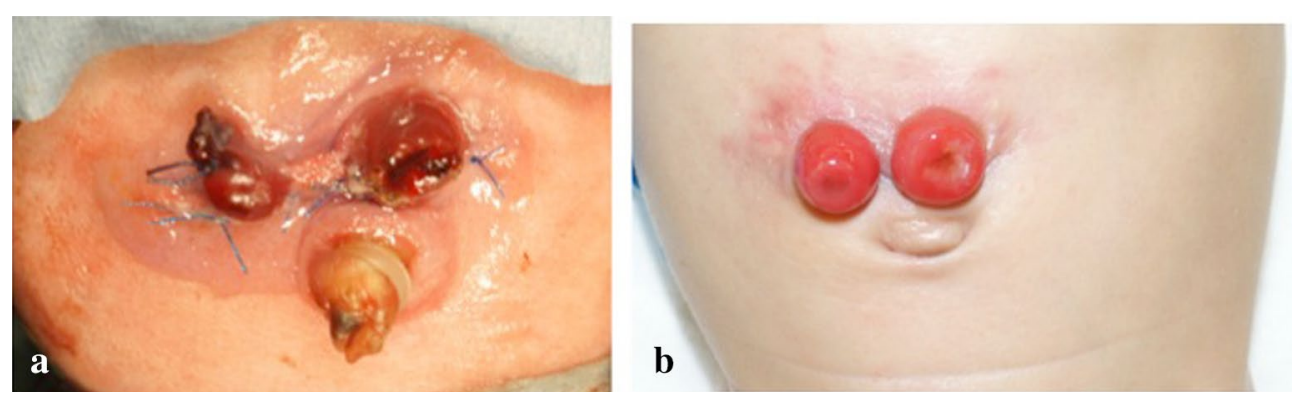

Fig. 2 The appearance of a stoma. a A stoma just after creation. b A stoma just before closure 
of a minimally invasive technique. It has been reported that 2-octyl cyanoacrylate, a tissue adhesive, can be safely and effectively used as a superficial wound closure alternative (Singer and Thode 2004; Coulthard et al. 2004; Farion et al. 2002). Experimental intestinal anastomosis for the bowel using 2-octyl cyanoacrylate has been reported (Paral et al. 2011; Irkorucu et al. 2009; Kanellos et al. 2002). Cyanoacrylate adhesives allow for a shorter operation and resulted in greater satisfaction for both patients and surgeons in comparison to sutures (Farion et al. 2002). Furthermore, their use is associated with fewer infections, easier wound management, and subsequently, is more cost-effective (Wong et al. 2011; Aslam and Hunter 2009).

The complications of intestinal stomas in ELBW infants are often caused by the surgical techniques used. The thickness of the bowel wall in ELBW infants is similar to the diameter of the needles commonly used, which is $70 \mu \mathrm{m}$ for $6-0$, and $100 \mu \mathrm{m}$ for 5-0 (Faingold et al. 2005; Epelman et al. 2007). It is therefore understandable that a needle stick can easily lead to a penetration of the bowel wall (Rygl et al. 2009; Faingold et al. 2005; Epelman et al. 2007). Tissue adhesives do not require needles, and thus eliminate the risk of breaking the bowel wall. Indeed, the present study showed no complications associated with stoma creation in our cases. The appearance of the stoma was relatively good, and it was easy to manage the skin around the stomas.

In this study, the use of cyanoacrylate adhesive did not reduce the length of the operation compared to the prior cases where sutures were used (data not shown). The length of the operation is affected not only by surgical procedures, including inspection of the affected bowel and stoma creation, but also the degree of intraperitoneal adhesion due to peritonitis. Thus, given the complicated nature of the procedure and the poor general health of ELBW infants, it was not surprising that there was no significant decrease in the length of the operation. The mortality of affected patients is associated with various factors, such as sepsis, peritonitis, the general condition and the degree of existing IVH (intraventricular hemorrhage) at the time of the surgery. This study demonstrated that the use of the liquid tissue adhesive for creating a stoma in ELBW infants could reduce the incidence of postoperative complications related to stoma creation, thus improving the outcome for the patients. Cyanoacrylate adhesives can simplify the surgical techniques, and thus make such patients easier to manage.

In conclusion, this study demonstrated that the use of cyanoacrylate adhesives in ELBW infants may have the potential to reduce the length of the operation and the incidence of complications related to the stoma. Although accumulation and analysis of large numbers of
ELBW infants and cumulative data of using this sutureless technique are needed to verify this safety observation, this pilot study showed the use of cyanoacrylate tissue adhesives is recommended as alternative for stoma creation in these premature infants.

\section{Authors' contributions}

SN and $\mathrm{HO}$ conceptualized the method; SN, HO, TS and RS developed it; SN drafted the manuscript, and had the primary responsibility for its content; KM Clinical. All authors read and approved the final manuscript.

\section{Author details}

${ }^{1}$ Department of Pediatric Surgery, Hyogo College of Medicine, Nishinomiya 663-8501, Hyogo, Japan. ${ }^{2}$ Department of Neonatology, Hyogo College of Medicine, Nishinomiya 663-8501, Hyogo, Japan. ${ }^{3}$ Department of Pediatric Surgery, Osaka University Graduate School of Medicine, Suita 565-0871, Osaka, Japan.

\section{Competing interests}

The authors declare that they have no competing interests.

Received: 28 July 2015 Accepted: 15 February 2016

Published online: 27 February 2016

\section{References}

Aslam MI, Hunter DC (2009) Does liquid tissue adhesive increase satisfaction with wound and stoma management after surgery? J Wound Care 18(9):391-394

Blakely ML, Lally KP, McDonald S, Brown RL, Barnhart DC, Ricketts RR, Thompson WR, Scherer LR, Klein MD, Letton RW, Chwals WJ, Touloukian RJ, Kurkchubasche AG, Skinner MA, Moss RL, Hilfiker ML (2005) Postoperative outcomes of extremely low birth-weight infants with necrotizing enterocolitis or isolated intestinal perforation: a prospective cohort study by the NICHD Neonatal Research Network. Ann Surg 241 (6):984-989; discussion 989-994

Coulthard P, Worthington H, Esposito M, Elst M, Waes OJ (2004) Tissue adhesives for closure of surgical incisions. Cochrane Database Syst Rev (2):CD004287. doi:10.1002/14651858.CD004287.pub2

Eicher C, Seitz G, Bevot A, Moll M, Goelz R, Arand J, Poets C, Fuchs J (2012) Surgical management of extremely low birth weight infants with neonatal bowel perforation: a single-center experience and a review of the literature. Neonatology 101(4):285-292. doi:10.1159/000335325

Epelman M, Daneman A, Navarro OM, Morag I, Moore AM, Kim JH, Faingold R, Taylor G, Gerstle JT (2007) Necrotizing enterocolitis: review of state-ofthe-art imaging findings with pathologic correlation. Radiographics 27(2):285-305. doi:10.1148/rg.272055098

Faingold R, Daneman A, Tomlinson G, Babyn PS, Manson DE, Mohanta A, Moore AM, Hellmann J, Smith C, Gerstle T, Kim JH (2005) Necrotizing enterocolitis: assessment of bowel viability with color doppler US. Radiology 235(2):587-594. doi:10.1148/radiol.2352031718

Faion AG, Diogo Filho A, de Alcantara TM, Ferreira TF (2011) Ethyl-2-cyanoacrylate as a sealant after partial cecum resection in rattus norvegicus albinus. Rev Col Bras Cir 38(1):45-53

Farion K, Osmond MH, Hartling L, Russell K, Klassen T, Crumley E, Wiebe N (2002) Tissue adhesives for traumatic lacerations in children and adults. Cochrane Database Syst Rev (3):CD003326. doi:10.1002/14651858.CD003326

Gollin G, Abarbanell A, Baerg JE (2003) Peritoneal drainage as definitive management of intestinal perforation in extremely low-birth-weight infants. J Pediatr Surg 38(12):1814-1817

Hunter CJ, Chokshi N, Ford HR (2008) Evidence vs experience in the surgical management of necrotizing enterocolitis and focal intestinal perforation. J Perinatol 28(Suppl 1):S14-17. doi:10.1038/jp.2008.44

Irkorucu O, Ucan BH, Cakmak GK, Tascilar O, Emre AU, Ofluoglu E, Bahadir B, Karakaya K, Demirtas C, Pasaoglu H, Ankarali H, Comert M (2009) Effect of 2-octyl-cyanoacrylate on ischemic anastomosis of the left colon. J Invest Surg 22(3):188-194. doi:10.1080/08941930902866261 
Kanellos I, Mantzoros I, Demetriades H, Kalfadis S, Sakkas L, Kelpis T, Betsis D (2002) Sutureless colonic anastomosis in the rat: a randomized controlled study. Tech Coloproctol 6(3):143-146. doi:10.1007/s101510200033

Lai HS, Lin WH, Chen HA, Fan SZ, Chou HC (2010) Successful laparotomy in a $432 \mathrm{~g}$ extremely low-birth-weight infant with focal intestinal perforations. Int Surg 95(1):57-59

Michel JL, Harper L, Alessandri JL, Jacquemot L, De Napoli-Cocci S, Pilorget $H$, Samperiz S (2004) Peritoneal needle suction for intestinal perforation in the preterm neonate. Eur J Pediatr Surg 14(2):85-88. doi:10.105 5/s-2004-815853

Moss RL, Dimmitt RA, Barnhart DC, Sylvester KG, Brown RL, Powell DM, Islam S, Langer JC, Sato TT, Brandt ML, Lee H, Blakely ML, Lazar EL, Hirschl RB, Kenney BD, Hackam DJ, Zelterman D, Silverman BL (2006) Laparotomy versus peritoneal drainage for necrotizing enterocolitis and perforation. $N$ Engl J Med 354(21):2225-2234. doi:10.1056/NEJMoa054605

Murthy K, Yanowitz TD, DiGeronimo R, Dykes FD, Zaniletti I, Sharma J, Sullivan KM, Mirpuri J, Evans JR, Wadhawan R, Piazza A, Adams-Chapman I, Asselin JM, Short BL, Padula MA, Durand DJ, Pallotto EK, Reber KM (2014) Shortterm outcomes for preterm infants with surgical necrotizing enterocolitis. J Perinatol 34(10):736-740. doi:10.1038/jp.2014.153

Ong CC, Jacobsen AS, Joseph VT (2002) Comparing wound closure using tissue glue versus subcuticular suture for pediatric surgical incisions: a prospective, randomised trial. Pediatr Surg Int 18(5-6):553-555. doi:10.1007/ s00383-002-0728-0

Paral J, Subrt Z, Lochman P, Klein L, Hadzi-Nikolov D, Turek Z, Vejbera M (2011) Suture-free anastomosis of the colon. Experimental comparison of two cyanoacrylate adhesives. J Gastrointest Surg 15(3):451-459. doi:10.1007/ s11605-010-1370-0

Rees CM, Pierro A, Eaton S (2007) Neurodevelopmental outcomes of neonates with medically and surgically treated necrotizing enterocolitis. Arch Dis Child Fetal Neonatal Ed 92(3):F193-198. doi:10.1136/adc.2006.099929
Rees CM, Eaton S, Kiely EM, Wade AM, McHugh K, Pierro A (2008) Peritoneal drainage or laparotomy for neonatal bowel perforation? A randomized controlled trial. Ann Surg 248(1):44-51. doi:10.1097/ SLA.0b013e318176bf81

Rygl M, Novotna J, Herget J, Skaba R, Snajdauf J (2009) Parameters of healing in approximative intestinal anastomosis. Eur J Pediatr Surg 19(1):25-29. doi:10.1055/s-2008-1039010

Saleemi MS, McLaren C, Sharma BK, Muthialu N, Roebuck D, Ng C (2013) Bronchopleural fistula in a newborn undergoing ECMO-transbronchial closure. J Perinatol 33(8):659-660. doi:10.1038/jp.2012.159

Singer AJ, Thode HC Jr (2004) A review of the literature on octylcyanoacrylate tissue adhesive. Am J Surg 187(2):238-248. doi:10.1016/j.amjsurg.2003.11. 01750002961003005105

Sola JE, Tepas JJ 3rd, Koniaris LG (2010) Peritoneal drainage versus laparotomy for necrotizing enterocolitis and intestinal perforation: a meta-analysis. J Surg Res 161 (1):95-100. doi:10.1016/j.jss.2009.05.007

Vida VL, Barzon E, Sabiu C, De Franceschi M, Padalino MA, Stellin G (2015) The use of "2-octyl cyanoacrylate" as skin adhesive in pediatric and congenital cardiac surgery. Minerva Pediatr 67(2):111-116

Voznesensky M, Mutter C, Hayn M, Kinkead T, Jumper B (2015) Pediatric sutureless circumcision: an effective and cost efficient alternative. Can J Urol 22(5):7995-7999

Weiss M, Haj M (2001) Gastrointestinal anastomosis with histoacryl glue in rats. J Invest Surg 14(1):13-19

Wong EM, Rainer TH, Ng YC, Chan MS, Lopez V (2011) Cost-effectiveness of Dermabond versus sutures for lacerated wound closure: a randomised controlled trial. Hong Kong Med J 17(Suppl 6):4-8

\section{Submit your manuscript to a SpringerOpen ${ }^{\odot}$ journal and benefit from:}

- Convenient online submission

- Rigorous peer review

- Immediate publication on acceptance

- Open access: articles freely available online

- High visibility within the field

- Retaining the copyright to your article

Submit your next manuscript at $>$ springeropen.com 